\title{
Stages of Civic Identity Formation
}

\section{Етапи становлення громадянської ідентичності особистості}

\author{
Inha Petrovska \\ Ph.D. in Technical Sciences, \\ Assistant Professor \\ Інга Петровська \\ кандидат технічних наук, \\ доцент \\ E-mail:inha.petrovska@lnu.edu.ua \\ orcid.org/0000-0001-7544-945X \\ Researcher ID: B-8482-2019 \\ Ivan Franko National University \\ of Lviv, Lviv, Ukraine \\ 1, Universytetska str, Lviv, \\ 79000 \\ Львівський національний \\ університет ілені \\ Івана Франка \\ вул. Університетська, 1, \\ м. Львів, 79000 \\ Original manuscript received February 03, 2019 \\ Revised manuscript accepted March 01, 2019
}

\begin{abstract}
It has been noted that the formation of civic identity occurs by stages and takes place in the process of civic socialization, which is proposed to be regarded as the process of gaining social experience of civicism by an individual (norms and values of civic culture, civic behavior patterns, knowledge and ideas about the state, citizenship, etc.) through the inclusion into the organizational environment of the state and the system of social relations with other citizens. There are four stages of civic identity formation: informationalperceptual, content-normative, value-semantic and integration-identification.

It has been shown that the informational-perceptual stage (covering pre-school and early school age) is a stage of initial awareness, immature awareness, characterized by the presence of fragmentary and non-systema-
\end{abstract}

ISSN 2227-6246 (Print) / ISSN 2663-6956 (Online) 
tic representations and knowledge about citizenship, state, etc. formed as a result of recording of messages (mostly implicit ones) regarding civic norms and values, observation of the civic behavior of others. The content-normative stage (encompassing secondary school / teenage age) is characterized by the formation of ideas about the social role of a citizen, awareness of the system of civil rights and duties, ideals and values, as well as the formation of perceptions of oneself as similar to the citizens of own state and different from the citizens of another state (self-categorization); the system of civic guidance begins to emerge. The value-semantic stage (covering adolescence) involves the identification and justification of the value-semantic foundations of own life concept, determination of the interest direction, in particular regarding the socio-political sphere, formation of ideas about oneself as a citizen and a value-estimating attitude towards civic affiliation. Integration-identification stage (covering the early adulthood period) is characterized by crystallization, formation of attitude (cognitive, affective, conative), value-semantic, spatiotemporal (self-realization) and active-transforming (subject activity) aspects of the personality that contributes to the new mental formation (personal structure) - civic identity.

Key words: civic identity, civic socialization, stages of formation, civic subjectivity, self-categorization.

\section{Вступ}

Громадянська ідентичність особистості - це складне багаторівневе особистісне утворення, що $є$ результатом самокатегоризації, осмислення (надання сенсу-цінності) своєї приналежності до спільноти громадян і держави та суб'єктивного ставлення (емотивного й конативного) особи до свого членства. Громадянська ідентичність розглядається нами як різновид організаційної ідентичності (Петровська, 2018: 246).

Становлення громадянської ідентичності особистості відбувається у процесі гроладянської соиіалізацї, яку на основі загальноприйнятих визначень соціалізації та організаційної соціалізації визначаємо як процес засвоєння індивідол соиіального досвіду гроладянськості (норм і цінностей громадянської культури, зразків громадянської поведінки, знань і уявлень щодо держави, громадянства 
тощо) шляхол включення в організаційне середовище держави і систелу соиіальних зв'язків з іншили гроладянали. Увага до громадянської ідентичності особливо актуалізувалася за останні два десятиріччя. Зарубіжні та вітчизняні науковці намагаються визначити її сутнісні характеристики, зокрема відмінності громадянської ідентичності від етнонаціональної ідентичності (Hart, Richardson \& Wilkenfeld, 2011; Hristova \& Cekik, 2013; Taljunaite, 2013; Yates \& Youniss, 2006; Васютинський, 2011; Горностай, 2015; ЗЖадан, 2017; Хазратова, 2016), виокремити її структурні компоненти (Cohen \& Chaffee, 2013; Безгина, 2013; Ефименко, 2013; Петровська, 2017). Однак щодо особливостей становлення громадянської ідентичності особистості в науковій літературі існують лише фрагментарні висловлювання вчених.

Мета статті - проаналізувати та з'ясувати змістовне наповнення етапів становлення громадянської ідентичності особистості.

\section{Завдання статті}

1. Виокремити етапи становлення громадянської ідентичності особистості.

2. Охарактеризувати особливості наповнення когнітивного, ціннісного, емоційно-мотиваційного і конативного (поведінкового) компонентів громадянської ідентичності на різних етапах її становлення.

\section{Методи та методики дослідження}

Етапи становлення громадянської ідентичності були виокремлені нами на підставі: 1) особливостей соціального розвитку особистості (особливостей формування їі соціального досвіду), що охоплює сфери свідомості, спілкування та діяльності й передбачає: формування і розвиток свідомості, світогляду людини (засвоєння поглядів, інтересів, соціальних цінностей, ідеалів); оволодіння культурою, властивою певному суспільству, соціальній 
спільності (правилами, нормами і шаблонами поведінки); засвоєння соціальних ролей, навичок спілкування, самовияву в середовищі життєдіяльності; накопичення досвіду соціальної поведінки (Москаленко, 2013); 2) основних фаз становлення особистості (адаптації - засвоєння соціальних норм і цінностей; індивідуалізації - прагнення особистості до власної персоналізації та самоактуалізації; інтеграції - входження особистості в соціальну групу, в якій відбувається розкриття їі можливостей) (Петровський, 2003); 3) стадіального характеру становлення ідентичності (Еріксон, 1996; Магсіа, 1966; ЖЋадан, 2017; Колотаєв \& Улибіна, 2012; Максименко, 2006); 4) особливостей гроладянської соціалізацї як різновиду організаційної соціалізацї̈ (Петровська, 2018).

\section{Результати та дискусії}

На нашу думку, основними етапами становлення громадянської ідентичності є інформаційно-перцептивний, змістовно-нормативний, ціннісно-смисловий та інтеграційно-ідентифікаційний (рис. 1).

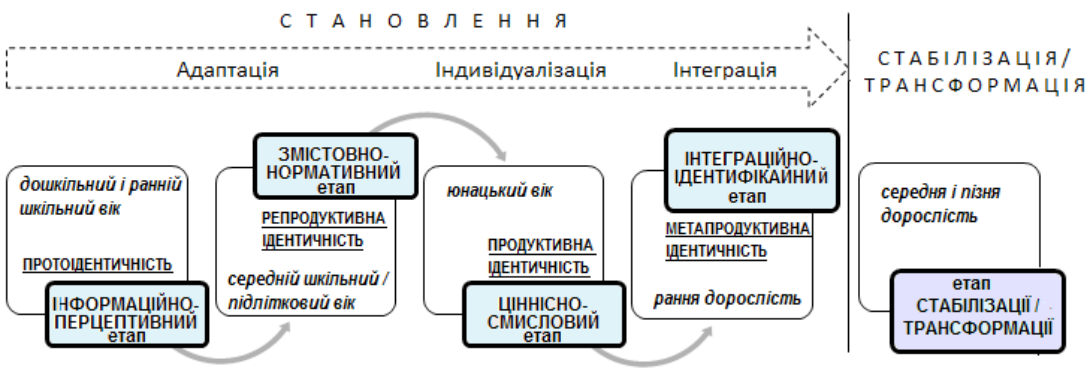

Puc. 1. Етапи становлення громадянської ідентичності особистості

Інфорлаиійно-периептивний етап характеризується наявністю фрагментарних і несистематичних уявлень і знань щодо громадянства, держави, державних символів, героїв, свят, солідарності тощо, які формуються внаслідок 
фіксування повідомлень (переважно неявних) щодо громадянських норм і цінностей, спостереження громадянської поведінки інших. Це етап початкової поінформованості, незрілого усвідомлення, з провідним мотивом - орієнтувально-пізнавальним. Цьому етапу відповідає так звана протоіәентичність (Колотаєв \& Улибіна, 2012: 64), коли власна громадянська ідентичність ще не є проблематизованою (рівень рефлексії нульовий) і сприймається як природний стан за фактом приналежності до спільноти громадян і держави. Зазначений етап також схожий на перший етап становлення організаційної ідентичності - етап ініціацїі, що передбачає ознайомлення з організацією, її історією, звичаями, обрядами, символікою, з поступовим посвяченням у її ритуали та цінності (Устинова \& Чуприна, 2014: 50).

Інфорлаційно-периептивний етап становлення громадянської ідентичності відповідає першому рівню громадянської самоідентифікації - рівню знакової репрезентаuї (Ж゚адан, 2017), що характеризується такими особливостями, як зовнішня детермінація активності, несформованість ставленнєвого компонента, нерефлексованість цілей і цінностей, неусталеність практик громадянської взаємодії, ритуальні моделі громадянської активності, мінімальна інтегрованість у громадянську спільноту, невизначеність сенсу громадянства тощо.

На нашу думку, інформаційно-перцептивний етап становлення громадянської ідентичності співпадає з дошкільнил і ранніл шкільнил віком (5-10 років), коли через сім'ю, найближче оточення, дитячі колективи, засоби масової інформації відбувається початкова громадянська поінформованість.

Злістовно-норлативний етап характеризується формуванням уявлень про соціальну роль громадянина, обізнаністю щодо системи громадянських прав, свобод та обов'язків, ідеалів і цінностей, необхідності відповідати встановленим нормам, правилам і вимогам, а також формуванням уявлень про себе як про подібного до громадян 
своєї держави і відмінного від громадян іншої держави (самокатегоризація). На цьому етапі починає зароджуватися система громадянських настановлень, де провідними чинниками їх формування є соціальні потреби у приналежності, захисті, безпеці, а провідними мотивами громадянської ідентифікації є, відповідно, мотиви афіліації та захисту. Цьому етапу відповідає так звана репродуктивна ідентичність (Колотаєв \& Улибіна, 2012) із частковою відрефлексованістю. Конструювання дискурсу ідентичності спирається на норми і настанови, отримані з авторитетного джерела («справжній громадянин - це... ») (Ж⿱адан, 2017: 62). Зазначений етап подібний на другий етап становлення організаційної ідентичності особистості - етап інтеріоризацї критерїв $і$ норл організації (Устинова \& Чуприна, 2014: 50).

Змістовно-нормативний етап становлення громадянської ідентичності відповідає другому рівню громадянської самоідентифікації (за І. ЖАадан) - рівню інтерпретацї слислів, що характеризується переважанням зовнішньої детермінації, регулюванням активності користування засвоєними нормами і правилами, настановленнями відповідати очікуванням громади, прийняттям практик громадянської взаємодії (без рефлексіі), що пропонуються авторитетними іншими, традиційними, звичаєвими моделями громадянської активності, середньою інтегрованістю у громадянську спільноту (очікування захисту у відповідь на відданість) тощо (ЖАадан, 2017: 64-65).

Змістовно-нормативний етап становлення громадянської ідентичності, на нашу думку, співпадає із середніл шкільнил / підлітковим віком (11-15 років). На цьому етапі саме школа (освітні заклади) є одним із найважливіших інститутів цілеспрямованого впливу на процес становлення громадянської ідентичності молодої людини, формування її громадянських настановлень, особливо когнітивної (знання, уявлення, стереотипи, міфи тощо) й емоційної складових. При цьому не слід нехтувати і локаль- 
ними умовами дозрівання особистості в конкретній сім’ї, найближчому оточенні та соціальному середовищі (групи ровесників, дитячі організації, неформальні об’єднання). Одним із найважливіших джерел інформації стають також 3MI та інтернет-ресурси. Крім того, можливі деякі форми громадянської участі - ситуативні практики, що реалізуються в межах певного територіального (школа, район, місто) чи соціального (наприклад, соціальні мережі) простору у вигляді благодійної чи волонтерської діяльності.

Ціннісно-слисловий етап передбачає виокремлення та обгрунтування для себе ціннісно-смислових основ власної життєвої концепції, визначення спрямованості інтересів (базових соціальних настановлень), зокрема щодо громадсько-політичної сфери, формування уявлень про себе як громадянина і свої цілі й цінності, завдяки чому визначається ціннісно-оцінне ставлення до своєї громадянської приналежності - суб'єктивна значущість, важливість членства, котре інтерпретується як таке, що сприяє (чи ні) самоповазі та позитивному самоставленню; поділянняприйняття / неприйняття державницьких цінностей і цінностей громадянської спільноти. Провідними мотивами тут є мотиви самовизначення та самоповаги. Цьому етапу відповідає так звана продуктивна ідентичність (Колотаєв \& Улибіна, 2012) i, відповідно, третій етап становлення організаційної ідентичності, а саме та його частина, що пов'язана з усвіоолленнял і прийняттял / неприйняттял організаційних иінностей (Устинова \& Чуприна, 2014: 51).

Ціннісно-смисловий етап становлення громадянської ідентичності почасти відповідає третьому рівню громадянської самоідентифікації (за I. ЖКадан) - рівню конструювання слислів, що характеризується внутрішньою детермінацією активності, інтерпретацією та вибірковим присвоєнням пропонованих норм, цілей і цінностей, вибірковим прийняттям практик громадянської взаємодії (після аналізу доцільності активності), регламентованими 
законом моделями громадянської активності, високою інтегрованістю у громадянську спільноту (готовність відповідати за себе і близьких), сенс громадянства пов' язаний із мріями про майбутнє (Жадан, 2017: 64-65).

Ціннісно-смисловий етап становлення громадянської ідентичності співпадає з юнацькил вікол, що включає старший шкільний вік (ранню юність - 16-17 років) і старший юнацький вік (17-21 рік). У юнацькому віці особливо актуалізуються процеси самовизначення, процес фрормування самосвідомості та самоідентифікації досягає найвищих темпів. Саме в юнацькому віці формуються життєві плани, настанова на свідому побудову власного життя. Для переважної більшості людей саме в цьому віці відбувається професійне самовизначення, а отже, і визначення стилю життя та певного кола інтересів. Для юнацького віку, згідно Дж. Mарсіа, характерні передчасна ідентичність, мораторій і дифузія. Унаслідок успішного виходу з кризи цього віку повинна сформуватися досягнута ідентичність, і найкращою передумовою для цього є мораторій (Marcia, 1966: 553-554). Отже, юнацький вік є вирішальним для формування громадянської ідентичності.

Інтеграційно-ідентифікаційний етап характеризується кристалізацією, сформованістю ставленнєвих (когнітивних, афективних, конативних), ціннісно-смислових, просторово-часових (самореалізація) та діяльно-перетворюючих (суб’єктна активність) аспектів особистості, що сприяє формуванню психічного новоутворення (особистісного конструкту) - громадянської ідентичності.

Окремі структури особистості (система переконань (як кристалізація соціальних настановлень), ціннісні орієнтації та життєві плани (цілі), що, за А. Ватерманом i Дж. Mapcia, i є елементами ідентичності) набувають цілісності та формуються у систему. Цей період характеризується осмисленням і наданням своїй громадянській приналежності сенсу-цінності, формуванням суб'єктивного ставлення особистості до співгромадян і держави. 
Інтеграційно-ідентифікаційний етап передбачає безпосереднє включення та практичну залученість до суспільного, громадського життя, наявність власного досвіду активності у правовому, економічному, політичному просторі держави, взаємодії з державою у вигляді різноманітних їі інстанцій, установ, відомств (представниками державної влади - вертикальна взаємодія) та іншими співгромадянами (горизонтальна взаємодія), які мають спільні й типові проблеми їхнього життя в організаційній реальності держави, через колективну діяльність із досягнення спільного соціально значущого результату (можливий досвід участі в громадських організаціях, формалізованих і неформалізованих об’єднаннях й асоціаціях). Провідними мотивами на цьому етапі, крім мотиву самовизначення, є також мотиви соціальної самореалізації та покращення благоустрою держави і громадян.

Зміст і забарвленість соціальних настановлень залежатимуть, насамперед, від успішності особистості в практичній реалізації власних життєвих планів у організаційному просторі державі. На вже сформовані на попередньому (ціннісно-смисловому) етапі погляди та переконання суб'єкта «накладаються» його переживання стосовно життєвих успіхів і невдач.

Реалізація людини як особистості й громадянина у суспільстві та державі здійснюється через самовизначення й обрання активної позиції щодо суспільно виробленої системи цінностей (соціокультурних, громадянських, державницьких) i, як наслідок, через окреслення змісту та сенсу свого життя у державі як громадянина. Вирішується проблема взаємин себе і суспільства / держави, визначення себе в суспільстві / державі та через суспільство / державу. А це можливо здійснити у сфері цінностей і смислів. Так, несхожість кожного нового покоління з попередніми пояснюється тим, що кожне нове покоління здійснює особистісне самовизначення відносно іншої системи (ієрархії) цінностей, які існують у суспільстві. 
Цьому етапу відповідає так звана летапродуктивна ідентичність (Колотаєв \& Улибіна, 2012) і та частина третього етапу становлення організаційної ідентичності, що пов'язана з практичнил включеннял у діяльність організацї, спряловану на реалізацію організаційних иінностей (Устинова \& Чуприна, 2014: 51).

Інтеграційно-ідентифікаційний етап становлення громадянської ідентичності почасти відповідає четвертому рівню громадянської самоідентифікації (за І. ЖЋадан) - рівню конструювання улов і правил перетворення реальнос$m i$, що характеризується самопотенціюванням, конструюванням правил і практик громадянської взаємодії під конкретне завдання відповідно до особливостей ситуації та сенсу громадянства - перетворення реальності (ЖЖадан, 2017: 64-65).

Зазначений етап становлення громадянської ідентичності, на нашу думку, припадає на період ранньої дорослос$m i$, що охоплює першу фазу ранньої дорослості - молодість (21-30 років) і другу фазу ранньої дорослості (30-40 років). Період ранньої дорослості пов'язаний з активною реалізацією особистісного потенціалу особи у різних сферах життєдіяльності, визначенням ставлення до суспільно-політичного життя і своєї ролі в ньому. Світогляд, ідеали та цінності у цей період набувають стійкої форми (зникають сумніви і переживання часів юності), людина здобуває, за словами Б. Лівехуда, «основну домінантну структуру» (Павелків, 2015: 308), а саме життєву спрямованість (життєву стратегію, що спирається на життєву перспективу, яка створювалася на етапі від дошкільного до юнацького віку) - своєрідну схильність будувати і проживати життя саме так, а не інакше, знаходити в цьому переживання істинності, осмисленості свого життєвого шляху, узгодження своєї особистості, характеру й індивідуальності з обраним способом самореалізації в суспільстві, серед інших людей. Виявляється сильне прагнення до особистісної експансії, самовираження. Переживання, пов'язані зі станов- 
ленням і набуттям смисложиттєвих орієнтацій, втілюються у формулу «самореалізуватися», «усвідомити себе як цінність».

Ключовим переживанням соціальної ситуації розвитку ранньої дорослості є усвідомлення особистої відповідальності за своє життя, життя близьких, долю держави і суспільства, готовність прийняти цю відповідальність.

За словами Р. Павелківа, особливе значення ранньої дорослості полягає в тому, що, залучаючись до широкого різноманіття суспільних відносин, людина стає їх справжнім суб'єктом, свідомо формує індивідуальне ставлення до навколишнього світу (Павелків, 2015: 308), а відтак досягає ідентичності, зокрема і громадянської.

На інтеграційно-ідентифікаційному етапі в особи вже сформовані уявлення про державу та своє місце в ній, основні соціально-політичні / громадянські цінності, настановлення, уявлення і норми, усталені способи та практики громадянської взаємодії, що дають їй змогу самостійно i конструктивно виконувати свої громадянські ролі, діяти відповідно до своєї громадянської позиції.

Узагальнюючи вищесказане, представимо особливості наповнення компонентів громадянської ідентичності на кожному етапі її становлення.

Інфорлаційно-периептивний етап: когнітивний колпонент - фрагментарні уявлення / знання щодо громадянства та держави; иіннісний колпонент - громадянські цілі й цінності не рефлексовані; елоційно-лотиваційний колпонент - провідний мотив громадянської ідентифікації орієнтувально-пізнавальний, громадянські настановлення не сформовані; поведінковий колпонент - громадянська активність не актуалізована, мінімальна залученість в організаційний простір держави.

Змістовно-норлативний етап: когнітивний колпонент - уявлення про себе як про подібного до громадян своєї держави і відмінного від громадян іншої держави (самокатегоризація), уявлення про соціальну роль громадя- 
нина, обізнаність щодо громадянських прав та обов'язків; иіннісний колпонент - часткова відрефлексованість державницьких цінностей і цінностей громадянської спільноти; елоційно-лотиваційний колпонент - провідні мотиви громадянської ідентифікації - мотиви афіліації та захисту, зароджуються громадянські настановлення; поведінковий колпонент - громадянська активність носить ситуативноспонтанний характер, регулюється настановами, нормами і правилами, отриманими з авторитетного джерела, залученість в організаційний простір держави є середньою.

Ціннісно-слисловий етап: когнітивний колпонент актуалізовані процеси самовизначення, зокрема, про себе як громадянина; побудова життєвих планів, зокрема, у контексті можливостей самореалізації в державі; иіннісний колпонент - формування ціннісно-смислових основ власної життєвої концепції, ціннісно-оцінне ставлення до своєї громадянської приналежності - суб’єктивна значущість, важливість членства, котре інтерпретується як таке, що сприяє (чи ні) самоповазі та позитивному самоставленню; вибіркове поділяння-прийняття / неприйняття державницьких цінностей і цінностей громадянської спільноти; елоційно-лотиваційний колпонент - провідні мотиви громадянської ідентифікації - мотиви самовизначення та самоповаги, громадянські настановлення у стадії формування; поведінковий колпонент - прагнення визначитися зі сферами та формами громадянської активності, переважання внутрішньої детермінованості громадянської активності, залученість в організаційний простір держави є високою.

Інтеграційно-ідентифікаційний етап: когнітивний колпонент - сформоване чітке уявлення про себе як громадянина; кристалізація громадянських поглядів і переконань (зникають сумніви часів юності), що зумовлює відповідну громадянську позицію; усвідомлення особистої відповідальності за своє життя, життя близьких, долю держави і суспільства; иіннісний колпонент - осмислення 
та надання своїй громадянській приналежності сенсу-цінності, обрання активної позиції щодо суспільно виробленої системи цінностей (соціокультурних, громадянських, державницьких); елоиійно-лотиваиійний колпонент - громадянські настановлення сформовані, їх зміст і забарвленість залежать від успішності практичної реалізації власних життєвих планів у організаційному просторі держави; провідні мотиви громадянської ідентифікації - мотиви соціальної самореалізації та покращення благоустрою держави і громадян; поведінковий колпонент - максимальна практична включеність в організаційний простір держави (політичний, правовий, економічний тощо), громадянська активність внутрішньо детермінована, відповідно до сформованої власної громадянської позиції.

Варто зазначити, що громадянська соціалізація особистості може тривати впродовж усього свідомого життя людини, оскільки набуті уявлення, орієнтації, настанови не залишаються назавжди незмінними, вони можуть коригуватися, змінюватися і в зрілому, і навіть у похилому віці. Однак подальші зміни громадянської ідентичності $\epsilon$ вже не стільки їі формуванням, скільки трансформацією, що залежить від соціально-політичних, економічних та інших умов життєдіяльності людини.

У випадку руйнування раніше засвоєних норм і зразків поведінки, слідом за яким іде процес засвоєння або вироблення інших норм, прийнято говорити про ресоціалізацію: відбувається не просто засвоєння нових соціальних ніш, а переучування того, що було міцно засвоєно в дитинстві та юності й що становило фундамент цієї особистості (Шестопал, 2002: 135). Під громадянською ресоціалізацією ми розуміємо процес і результат інтеріоризації змінених норм і цінностей громадянської культури та державно-політичної системи, що призвело до трансформації базових громадянських настановлень і цінностей особистості, засвоєних у період ранньої громадянської соціалізації. 
Щодо особливостей громадянської ресоціалізації представників старшого покоління, то більшість із них продовжують усвідомлювати себе як частину радянської спільноти, попри завершення існування радянської держави, тобто мають елементи радянської ідентичності. Це покоління в дорослому стані опинилося перед викликом зміни інституційної системи суспільства, соціальних практик, норм і цінностей. У людей похилого віку присутня чітко виражена тенденція до поширення свого радянського досвіду на сучасне життя. Вони продовжують мислити радянськими категоріями й оперують системою радянських цінностей, де особа розчинялася в колективному «ми», а інтереси «я» були другорядними. Оцінка ними радянського минулого як політичної системи зводиться до наявності «порядку», «сильної руки», «дисципліни» (Молдавська, 2013: 41), дружньої психологічної атмосфери, коли люди готові прийти один одному на допомогу, та широких соціальних гарантій із боку держави (Беленок, 2012: 399). Поняття «демократія» $\epsilon$ абсолютно знівельованим у ціннісному аспекті людей похилого віку і вживається винятково у негативному контексті - для опису безладу та розрухи. Можливість свободи слова як результат демократії сприймається як дуже сумнівне завоювання (Молдавська, 2013: 42).

Згідно досліджень Л. Кожекіної, яка вивчала вплив інституційних змін у політичній системі пострадянського суспільства України на політичну ресоціалізацію «середнього» покоління, результатом ресоціалізації (що відбулася в середині їхнього життєвого шляху) стала масова маргіналізація «середнього» покоління. «Перехідне» покоління в 1990-і рр. відзначалося найвищим ступенем втрати своєї ідентичності з усіма соціальними і політичними групами, що належали і до колишньої суспільної системи, і до нової, яка тільки формувалася (Кожекіна, 2013: 71).

Отже, зміна типу політичної та інституційної систем суспільства (після розпаду СРСР) зумовила трансформацію громадянської ідентичності значної частини населення. 
Старше та середнє покоління дотепер стикаються з необхідністю адаптації до нових соціально-політичних реалій, нових цінностей, декларованих владою, нових норм і правил гри. Цей процес внутрішньоособистісних диспозиційних змін є болісним і тривалим та, як правило, проходить на тлі загальної суспільної кризи. Водночас відомо, що оновлення ціннісної системи суспільства вимагає більше часу, ніж модернізація політичних інститутів. Ефект «запізнення» ціннісних змін створюе труднощі для процесу соціалізації громадян, у рамках якої вирішуються основні проблеми формування громадянської ідентичності.

\section{Висновки}

Становлення громадянської ідентичності носить стадіальний характер, проходить нерівномірно: спостерігаються як «спокійні», так і кризові періоди, та формується в міру усвідомлення і відрефрексування свого місця, ролі й ступеня активності в системі взаємодії з іншими громадянами і державою. До основних етапів становлення громадянської ідентичності відносимо: інформаційно-перцептивний, змістовно-нормативний, ціннісно-смисловий та інтеграційно-ідентифікаційний.

Становлення громадянської ідентичності особистості відбувається у процесі громадянської соціалізації за допомогою інститутів соціалізації мікросередовища (сім'я, близьке оточення особи) та макросередовища (культура, освітні заклади, ЗМІ, громадські організації тощо). Громадянська соціалізація розглядається нами як процес засвоєння індивідом соціального досвіду громадянськості (норм i цінностей громадянської культури, зразків громадянської поведінки, знань і уявлень щодо держави, громадянства тощо) шляхом включення в організаційне середовище держави і систему соціальних зв'язків з іншими громадянами.

Становлення громадянської ідентичності особистості пов’язане з розвитком її громадянської суб’єктності, що 
передбачає наявність активної громадянської позиції і передумовою становлення якої є ефективна громадянська соціалізація особистості.

\section{Література}

Безгина Н. В. К вопросу о построении структурной модели гражданской идентичности. Психосрера. Тула : Изд-во ТулГУ, 2013. С. 8-14.

Беленок А. Симптомы ностальгии по советскому прошлому в коллективных представлениях населения Украины. Соціальні виліри суспільства. 2012. № 4 (15). С. 390-410.

Васютинський В. О. Соціально-психологічні особливості самовизначення між українською і російською ідентичностями. Психологія мови і культури. 2011. С. 14-21.

Горностай П. П. Громадянська ідентичність українців та її еволюція. Проблели політичної психологї̈. 2015. № 2. С. 98-111.

Ефименко В. Н. Структурные компоненты и содержательное наполнение понятия «гражданская идентичность». Теория и практика общественного развития. 2013. № 11. С. 250-254.

Жадан I. В. Емпіричне дослідження особливостей громадянської та національної самоідентифікації молоді: базові поняття та показники. Наукові студї із соціальної та політичної психологї. 2017. № 39. С. $60-68$.

Кожекіна Л. Ю. Інституціональні зміни в політичній системі пострадянського суспільства України як чинник ресоціалізації «середнього» покоління. Украӥнський соціум. 2013. № 1 (44). С. 63-74.

Колотаев В. А., Улыбина Е. В. Стадиальная модель развития идентичности субъекта в культурно-историческом контексте (к проблеме роста самодетерминации в ее осуществлении). Мир психологии. 2012. № 1. C. 61-67.

Максименко С. Д. Генеза розвитку особистості. Київ : ТОВ «КММ», 2006. 240 с.

Молдавська Т. Радянська ідентичність та її вплив на формування сучасних суспільних стереотипів людей похилого віку. Наукові записки. 2013. № 12. С. 38-48.

Москаленко В. В. Соціалізація особистості: монографія. Київ : Фенікс, 2013. $540 \mathrm{c}$.

Павелків Р. В. Вікова психологія: підручник. Київ : Кондор, 2015. 469 с.

Петровська I. Р. Громадянська ідентичність як різновид організаційної ідентичності. Проблели сучасної психологї: зб. наук. праць Кал'янець-Подільського національного університету ілені Івана Огієнка, Інституту психологї ілені Г. С. Костюка НАПН України / За наук. ред. С. Д. Максименка, Л. А. Онуфрієвої. Кам'янецьПодільський : Аксіома, 2018. Вип. 39. С. 244-257. 
Петровська I. Р. Рівні та структура громадянської ідентичності особистості. Психологічні перспективи. Луцьк : СНУ імені Лесі Українки, 2017. № 30. С. 157-171.

Петровский А. В., Ярошевский М. Г. Теоретическая психология. Москва : Академия, 2003. 496 с.

Устинова О. В., Чуприна Е. В. Формирование корпоративной идентичности персонала. Вестник Челябинского государственного уни верситета. 2014. № 24 (353). С. 50-53.

Хазратова Н. В. До питання про психологічну природу громадянської ідентичності та її динаміку. Педагогічний процес: теорія $і$ практика. Серія: Психологія. 2016. № 3 (54). С. 78-84.

Шестопал Е. Б. Политическая психология: учебник для вузов. Москва : ИНФРА-М, 2002. 448 с.

Эриксон Э. Идентичность: юность и кризис. Москва : Прогресс, 1996. $344 \mathrm{c}$.

Cohen, A. K., \& Chaffee, B. W. (2013). The relationship between adolescents' civic knowledge, civic attitude, and civic behavior and their self-reported future likelihood of voting. Education, Citizenship and Social Justice, 8 (1), 43-57.

Hart, D., Richardson, C., \& Wilkenfeld, B. (2011). Civic Identity. Handbook of Identity. Theory and Research, 771-787.

Hristova, L., \& Cekik, A. (2013). Between the ethnic and the civic identity - on the perceptions of the student population in the Republic of Macedonia. New Balkan Politics, 13, 45-70.

Marcia, J. E. (1966). Development and validation of ego-identity status. Journal of personality and social psychology, 3 (5), 551-558.

Taljunaite, M. (2013). From ethnic and civil identity towards state identity. Filosofija-Sociologija, 24 (4), 187-192.

Yates, M., \& Youniss, J. (2006). Roots of Civic Identity. International Perspectives on Community Service and Activism in Youth. Cambridge University Press.

\section{References}

Bezgina, N. V. (2013). K voprosu o postroenii strukturnoj modeli grazhdanskoj identichnosti [On the question of building a structural model of civic identity]. Psihosfera-Psychosphere. Tula : TulGU, 8-14 [in Russian].

Belenok, A. (2012). Simptomy nostal'gii po sovetskomu proshlomu v kollektivnyh predstavlenijah naselenija Ukrainy [Symptoms of nostalgia for the Soviet past in the collective views of the population of Ukraine]. Sotsialni vymiry suspilstva - Social surveys of society, 4 (15), 390-410 [in Russian]. 
Vasiutynskyi, V. O. (2011). Sotsialno-psykholohichni osoblyvosti samovyznachennia mizh ukrainskoiu i rosiiskoiu identychnostiamy [Sociopsychological peculiarities of self-determination between Ukrainian and Russian identities]. Psykholohiia movy i kultury - Psychology of Language and Culture, 14-21 [in Ukrainian].

Hornostai, P. P. (2015). Hromadianska identychnist ukraintsiv ta yii evoliutsiia [Ukrainian civic identity and its evolution]. Problemy politychnoi psykholohii - Problems of Political Psychology, 2, 98-111 [in Ukrainian].

Efimenko, V. N. (2013). Strukturnye komponenty i soderzhatel'noe napolnenie ponjatija "grazhdanskaja identichnost" [Structural components and meaningful content of the concept «civic identity»]. Teorija i praktika obshchestvennogo razvitija - Theory and Practice of Social Development, 11, 250-254 [in Russian].

Zhadan, I. V. (2017). Empirychne doslidzhennia osoblyvostei hromadianskoi ta natsionalnoi samoidentyfikatsii molodi: bazovi poniattia ta pokaznyky [Empirical study of the peculiarities of civic and national self-identification of youth: basic concepts and indicators]. Naukovi studii iz sotsialnoi ta politychnoi psykholohii - Scientific studies on social and political psychology, 39, 60-68 [in Ukrainian].

Kozhekina, L. Yu. (2013). Instytutsionalni zminy v politychnii systemi postradianskoho suspilstva Ukrainy yak chynnyk resotsializatsii "serednoho» pokolinnia [Institutional changes in the political system of post-Soviet Ukraine as a factor in the re-socialization of the «middle» generation]. Ukrainskyi sotsium - Ukrainian socium, 1 (44), 63-74 [in Ukrainian].

Kolotaev, V. A., \& Ulybina, E. V. (2012). Stadial'naja model' razvitija identichnosti sub'ekta v kul'turno-istoricheskom kontekste (k probleme rosta samodeterminacii v eje osushchestvlenii) [Stadial model of development of the identity in the cultural and historical context (to the problem of the growth of self-determination in its implementation)]. Mir psihologii - The World of Psychology, 1, 61-67 [in Russian].

Maksymenko, S. D. (2006). Geneza rozvytku osobystosti [Genesis of personality development ]. Kyiv : TOV «KMM» [in Ukrainian].

Moldavska, T. (2013). Radianska identychnist ta yii vplyv na formuvannia suchasnykh suspilnykh stereotypiv liudei pokhyloho viku [Soviet identity and its influence on the formation of modern social stereotypes of the elderly]. Naukovi zapysky - Scientific notes, 12, 38-48 [in Ukrainian].

Moskalenko, V. V. (2013). Sotsializatsiia osobystosti [Socialization of personality]. Kyiv : Feniks [in Ukrainian].

Pavelkiv, R. V. (2015). Vikova psykholohiia [Age-related psychology]. Kyiv : Kondor [in Ukrainian]. 
Petrovska, I. R. (2018). Hromadianska identychnist yak riznovyd orhanizatsiinoi identychnosti [Civic identity as a type of organizational identity]. Problemy suchasnoi psykholohii-Problems of Modern Psychology: Collection of research papers of Kamianets-Podilskyi National Ivan Ohiienko University, G. S. Kostiuk Institute of Psychology of National Academy of Educational Sciences of Ukraine, 39, 244-257. Kamianets-Podilskyi : Aksioma [in Ukrainian].

Petrovska, I. R. (2017). Rivni ta struktura hromadianskoi identychnosti osobystosti [Personality's civic identity levels and structure]. Psykholohichni perspektyvy - Psychological perspectives, 30, 157-171 [in Ukrainian].

Petrovskij, A. V., \& Jaroshevskij, M. G. (2003). Teoreticheskaja psihologija [Theoretical psychology]. Moskva : Akademija [in Russian].

Ustinova, O. V., \& Chuprina, E. V. (2014). Formirovanie korporativnoj identichnosti personala [Formation of staff corporate identity]. Vestnik Cheljabinskogo gosudarstvennogo universiteta - Newsletter of Cheliabinsk State University, 24 (353), 50-53 [in Russian].

Khazratova, N. V. (2016). Do pytannia pro psykholohichnu pryrodu hromadianskoi identychnosti ta yii dynamiku [On the question of the psychological nature of civic identity and its dynamics]. Pedahohichnyi protses: teoriia i praktyka. Seriia: Psykholohiia - Pedagogical Process: Theory and Practice. Series: Psychology, 3 (54), 78-84 [in Ukrainian].

Shestopal, E. B. (2002). Politicheskaja psihologija [Political psychology]. Moskva : INFRA-M [in Russian].

Jerikson, Je. (1996). Identichnost': junost' i krizis [Identity: youth and crisis ]. Moskva : Progress [in Russian].

Cohen, A. K., \& Chaffee, B. W. (2013). The relationship between adolescents' civic knowledge, civic attitude, and civic behavior and their self-reported future likelihood of voting. Education, Citizenship and Social Justice, 8 (1), 43-57.

Hart, D., Richardson, C., \& Wilkenfeld, B. (2011). Civic Identity. Handbook of Identity. Theory and Research, 771-787.

Hristova, L., \& Cekik, A. (2013). Between the ethnic and the civic identity - on the perceptions of the student population in the Republic of Macedonia. New Balkan Politics, 13, 45-70.

Marcia, J. E. (1966). Development and validation of ego-identity status. Journal of personality and social psychology, 3 (5), 551-558.

Taljunaite, M. (2013). From ethnic and civil identity towards state identity. Filosofija-Sociologija, 24 (4), 187-192.

Yates, M., \& Youniss, J. (2006). Roots of Civic Identity. International Perspectives on Community Service and Activism in Youth. Cambridge University Press. 
Петровська Інга. Етапи становлення громадянської ідентичності особистосmi

\section{АНОТАЦІЯ}

Зазначено, що становлення громадянської ідентичності особистості носить стадіальний характер і відбувається у процесі громадянської сочіалізації, яку запропоновано розглядати як процес засвоєння індивідом соціального досвіду громадянськості (норм і иінностей громадянської культури, зразків громадянської поведінки, знань і уявлень щодо держави, громадянства тощо) шляхом включення в організаційне середовище держави і систему соціальних зв'язків з іншими громадянами. Виокремлено чотири етапи становлення громадянської ідентичності: інформаційно-перцептивний, змістовно-нормативний, ціннісно-смисловий та інтеграційно-ідентифікаційний. Показано, що інформаційно-перцептивний етап (охоплює дошкільний і ранній шкільний вік) $\epsilon$ етапом початкової поінформованості, незрілого усвідомлення, характеризується наявністю фрагментарних і несистематичних уявлень $і$ знань щодо громадянства, держави тощо, які формуються внаслідок фіксування повідомлень (переважно неявних) щодо громадянських норм і цінностей, спостереження громадянської поведінки інших. Змістовно-нормативний етап (охоплює середній шкільний / підлітковий вік) характеризується формуванням уявлень про соціальну роль громадянина, обізнаністю щодо системи громадянських прав та обов'язків, ідеалів і цінностей, а також фрормуванням уявлень про себе як про подібного до громадян своєї держави і відмінного від громадян іншої держави (самокатегоризація); починає зароджуватися система громадянських настановлень. Ціннісно-смисловий етап (охоплює юнацький вік) передбачає виокремлення й обгрунтування для себе ціннісно-смислових основ власної життєвої концепції, визначення спрямованості інтересів, зокрема щодо громадсько-політичної сфери, формування уявлень про себе як громадянина та иіннісно-оцінного ставлення до своєї громадянської приналежності. Інтеграційно-ідентифікаційний етап (охоплює період ранньої дорослості) характеризується кристалізацією, сформованістю ставленнєвих (когнітивних, афективних, конативних), ціннісно-смислових, просторово-часових (самореалізація) та діяльно-перетворюючих (суб'єктна активність) аспектів особистості, що сприяє фрормуванню психічного новоутворення (особистісного конструкту) - громадянської ідентичності. 
Ключові слова: громадянська ідентичність, громадянська соціалізація, етапи становлення, громадянська суб'єктність, самокатегоризачія.

\section{Петровская Инга. Этапы становления гражданской идентичности личности}

\section{АННОТАЦИЯ}

Отмечено, что становление гражданской идентичности личности носит стадиальный характер и происходит в процессе гражданской социализации, которую предложено рассматривать как процесс усвоения индивидом социального опыта гражданственности (норм и ценностей гражданской культуры, образцов гражданского поведения, знаний и представлений в отношении государства, гражданства и m. д.) путем включения в организационную среду государства и систему социальных связей с другими гражданами. Выделены четыре этапа становления гражданской идентичности: информационноперцептивный, содержательно-нормативный, ценностно-смысловой и интеграционно-идентификационный. Показано, что информационно-перцептивный этап (охватывает дошкольный и ранний школьный возраст) является этапом начальной осведомленности, незрелого осознания, характеризуется наличием фрагментарных и несистематических представлений и знаний о гражданстве, государстве и т. п., которые формируются в результате фиксирования сообщений (преимущественно неявных) о гражданских нормах и ченностях, наблюдения гражданского поведения других. Содержательно-нормативный этап (охватывает средний школьный / подростковый возраст) характеризуется формированием представлений о социальной роли гражданина, осведомленностью о системе гражданских прав и обязанностей, идеалов и ценностей, а также формированием представлений о себе как о подобном гражданам своего государства и отличающемся от граждан другого государства (самокатегоризация), начинает зарождаться система гражданских установок. Ценностно-смысловой этап (охватывает юношеский возраст) предусматривает выделение и обоснование для себя ценностно-смысловых основ собственной жизненной концепции, определения направленности интересов, в частности относительно общественно-политической сферы, формирование представлений о себе как гражданине и ченностно-оценочного отношения к своей гражданской принадлежности. Интеграционно-иден- 
тификационный этап (охватывает период ранней взрослости) характеризуется кристаллизацией, сформированностью установочных (когнитивных, афрективных, конативных), ценностно-смысловых, пространственно-временных (самореализация) и деятельно-преобразующих (субъектная активность) аспектов личности, способствует формированию психического новообразования (личностного конструкта) - гражданской идентичности.

Ключевые слова: гражданская идентичность, гражданская сочиализация, этапы становления, гражданская субъектность, самокатегоризация. 